\title{
Mercury Induces Cytotoxicity and Transcriptionally Activates Stress Genes in Human Liver Carcinoma $\left(\mathrm{HepG}_{2}\right)$ Cells
}

\author{
Dwayne J. Sutton ${ }^{1}$, Paul B. Tchounwou ${ }^{1}$, Nanuli Ninashvili ${ }^{1}$, and Elaine Shen $^{2}$ \\ ${ }^{1}$ Molecular Toxicology Research Laboratory, NIH-Center for Environmental Health, School of \\ Science and Technology, Jackson State University, 1400 Lynch Street, P.O. Box 18540, Jackson, \\ Mississippi 39217; Email: paul.b.tchounwou@jsums.edu \\ ${ }^{2}$ Xenometrix Research Laboratory, Xenometrix Inc., Boulder, Colorado 80301, USA.
}

Received: 7 June 2002 / Accepted: 30 September 2002 / Published: 30 September 2002

\begin{abstract}
Mercury is a non-essential element that exhibits a high degree of toxicity to humans and animals. Exposure to mercury has been associated with a significant number of adverse health effects including: cardiovascular disease, anemia, developmental abnormalities, neurobehavioral disorders, kidney and liver damage, and cancer in some cases. In several studies, the toxicity of mercury has been attributed to its high affinity to protein-containing sulfhydryl groups. However, little is known regarding the molecular mechanisms by which mercury exerts its toxicity, mutagenesis, and carcinogenesis. This research was therefore designed to assess the cellular and molecular responses of human liver carcinoma cells following exposure to mercury. Cytotoxicity was evaluated using the MTT-assay for cell viability, while the gene profile assay was performed to measure the transcriptional activation of stress genes in thirteen different recombinant cell lines generated from $\mathrm{HepG}_{2}$ cells. Cytotoxicity experiment yielded a $\mathrm{LD}_{50}$ value of $3.5 \pm 0.6$ $\mu \mathrm{g} / \mathrm{mL}$ upon 48 hours of exposure, indicating that mercury is highly toxic. A dose response relationship was recorded with respect to both cytotoxicity and gene induction. Overall, nine out of the thirteen recombinant cell lines tested showed inductions to statistically significant levels $(\mathrm{p}<0.05)$. At $2.5 \mu \mathrm{g} / \mathrm{mL}$ of mercury, the average fold inductions were 5.2 $\pm 0.9,21.4 \pm 3.9,7.0 \pm 6.2,6.8 \pm 1.1,2.7 \pm 1.0,4.5 \pm 2.0,7.5 \pm 6.0,2.2 \pm 0.7$, and $2.5 \pm 0.3$, for GSTYa, HMTIIA, c-fos, HSP70, CRE, p53RE, GADD153, GADD45, and GRP78, respectively. These results indicate the potential of mercury to undergo Phase II biotransformation in the liver (GSTYa), and to cause protein damage (HMTIIA, HSP70, and GRP78), cell proliferation ( $c$-fos), metabolic perturbation (CRE), growth arrest and DNA
\end{abstract}


damage (GADD153, GADD45), and apoptosis (p53RE). No significant inductions ( $>$ > 0.05) were observed for CYP1A1, XRE, NFkBRE, and RARE.

Keywords: Mercury, cytotoxicity, gene expression, $\mathrm{HepG}_{2}$ cells.

\section{Introduction}

Mercury is a toxic heavy metal that is of significant concern as an environmental pollutant [1]. It is a natural constituent of the earth's crust. Human activities have drastically altered the biogeo/chemical cycle and balance of mercury [2]. Mercury is a stable and persistent environmental contaminant since it cannot be degraded or destroyed. Therefore, it tends to accumulate in the soils and sediments. Excessive levels of mercury in the marine environment can affect marine biota and pose risk to human consumers of seafood. Hence, mercury compounds found in the marine environment pose risks to human health through the consumption of contaminated seafood.

Mercury and its compounds both inorganic and organic are released to the environment as a result of a variety of human activities [3]. Many metals are essential to life and only become toxic when exposures to biota become excessive (i.e. exceed some threshold for the induction of adverse effects). While certain non-essential metals do not have explicit exposure thresholds for the induction of adverse effects, the biological responses to mercury exposure are a direct consequence of exposure and are defined through a dose-effect relationship, where the risk of adverse effects is assumed to be proportional to the exposure. Accordingly, it is desirable to minimize such exposures to levels that do not cause adverse effects [4].

The main anthropogenic sources of mercury are various industrial point sources, including present and former mining activities, foundries and smelters, and diffuse sources such as combustion byproducts, constituents of products (i.e., agriculture, medicine, burning of fossil fuels, coals, etc.). Mercury is a relatively volatile heavy metal and can become attached to airborne particles and widely dispersed on a large scale. Mercury cycles in the environment as a result natural and human (anthropogenic) activities. The amount of mercury mobilized and released into the biosphere has increased since the beginning of the industrial age. Most of the mercury in the atmosphere is elemental mercury vapor, which circulates in the atmosphere for up to a year, and hence can be widely dispersed and transported thousands of miles from likely sources of emissions. Most of the mercury in water, soil, sediments, or plants and animals is in the form of inorganic mercury salts and organic forms of mercury (e.g., methyl mercury). The inorganic form of mercury, when either bound to airborne particles or in a gaseous form, is readily removed from the atmosphere by precipitation and/or dry deposition. Wet deposition is the primary mechanism for transporting mercury from the atmosphere to surface waters and land. Even after it deposits, mercury commonly is emitted back to the atmosphere either as a gas or associated with particles to be redeposited elsewhere. As it cycles 
between the atmosphere, the land, and water, mercury undergoes a series of complex chemical and physical transformations, many of which are not completely understood [5].

The mercury cycle in the environment is further complicated by the fact that in the environment there is a constant inter-conversion between various forms of mercury through oxidation and reduction reactions [6]. Unlike most pollutants whose movement is limited to erosion or leaching pathways, elemental mercury is readily transported into the atmosphere, and has an atmospheric half-life of approximately one year. Elemental mercury is eventually removed from the atmosphere by oxidation to a water-soluble species and by dry deposition. Although large-scale releases of mercury have been controlled in the United States, atmospheric transport implicates smaller sources (combustion of coal, municipal solid waste and sewage sludge) as the cause of widespread elevations of mercury concentrations in remote ecosystems [7].

There are many processes and symptoms of mercury toxicity. Poisoning can come from four categories of mercury; metallic or elemental mercury, which is relatively mild; inorganic mercury, such as mercury chlorides, which primarily affect the kidneys; organo-mercurials, such as mercury salts in diuretics or fungicides, which convert to inorganic mercury; and short chain alkyl mercury compounds, of which methyl mercury is the most toxic [8].

Acute symptoms are caused mainly by mercuric chloride or methyl mercury exposure. Chronic, lower level exposure may lead to specific symptoms or to subtle renal and nervous system problems. Inhaled mercury has a different effect than ingested mercury, for which most symptoms are related to the gastrointestinal tract and the nervous system. Inhaling high levels of metallic mercury (in an industrial setting/dentist's office) can cause acute symptoms such as fever, chills, coughing, and chest pain. With low, long-term exposure, more subtle symptoms such as fatigue, headache, insomnia, nervousness, impaired judgment and coordination, emotional liability, and loss of sex drive, may be experienced. Ingested mercury may cause stomatitis and gastrointestinal inflammation, with nausea, vomiting, abdominal pain, and bloody diarrhea, progressing to neurological problems. These symptoms, which are often confused with psychogenic causes, are referred to a "micromercurialism" [9].

Mild or early symptoms of mercury intoxication include fatigue, insomnia, irritability, anorexia, and loss of sex drive, headache, and forgetfulness or poor memory. This may lead to other nervous system symptoms such as dizziness, tremors in coordination, and depression; then progress to numbness and tingling, most commonly of the hands, feet, or lips; and to further weakness, worse memory and coordination, reduced hearing and speech paralysis and psychosis [10]. Mercury toxicity may be a factor in multiple sclerosis. Other problems of severe mercury intoxication are kidney and brain damage, as well as birth defects in pregnant women. Luckily, these symptoms are unusual. However, the subtle and nervous system symptoms from chronic exposure may be more common than is realized [11]. 
Mercury is a more significant pollutant than other heavy metals because of its complex environmental chemistry and extreme toxicity. While both the absorption and toxicity of mercury in biological systems vary with the chemical complex of the metal, environmental pathways can result in transmutations between different species of mercury. Mercury is most problematic when present in an organic compound such as the case with methyl or dimethyl mercury. Methyl mercury is formed from inorganic mercury by aquatic microorganisms and biomagnified in the aquatic food web. Because of the potential for methylation and bioaccumulation, even trace amounts of mercury deposited from the atmosphere to the surface waters remain a significant cause of concern across the United States and much of the rest of the world.

Metalloproteins are involved in the transport and detoxification of mercury $[12,13]$. Mercury inhibits sulfur ligands, which inactivates metalloproteins that normally bind metal ions such as copper [14]. This allows the level of copper to reach toxic levels in many membranes. Exposure to mercury also results in changes in metalloprotein compounds that have genetic effects (both structural and catalytic) on gene expression [15]. Some of the processes affected by this control of gene expression include cellular respiration, metabolism, enzymatic processes, metal specific homeostasis, and adrenal stress response systems [16].

Previous research has documented that mercury is cytotoxic. Its biochemical damage at the cellular level includes DNA damage, and inhibition of DNA and RNA synthesis [17]. Mercury also causes alterations in protein structure, alterations in calcium transport, along with the inhibition of glucose transport and enzyme function [18, 19]. It also interferes with essential nutrients by the replacement of essential minerals such as zinc at sites in enzymes. This is a part of the toxic effect of mercury that disables the enzymatic process.

A direct mechanism involving mercury's inhibition of cellular enzymatic processes by binding with the hydroxyl radical (SH) in amino acids appears to be a major part of the connection to allergic/immune reactive conditions [20]. Additional cellular level enzymatic effects of mercury binding with proteins include the blockage of sulfur oxidation processes [21], enzymatic processes involving vitamins B6 and B12 [22], effects on cytochrome-c energy processes [23], along with mercury's adverse effect on the cellular mineral levels of calcium, magnesium, zinc, and lithium [24]. Mercury has also been found to cause additional neurological immune system effects through immune/autoimmune reactions [25].

Based on the chemical, biological, and environmental characteristics of the various forms of mercury, it has been established that inorganic mercury is the form most likely to pose a hazard in drinking water. A maximum contaminant level goal (MCLG) and maximum contaminant level (MCL) of $0.002 \mathrm{mg} / \mathrm{L}$ have been established for inorganic mercury [26]. The World Health Organization has developed a guideline of $0.001 \mathrm{mg} / \mathrm{L}$ for all forms of mercury in drinking water [27]. Inorganic mercury has also been evaluated for carcinogenic potential. Mercuric chloride has been classified by the U.S. Environmental Protection Agency (U.S. EPA) as a possible human carcinogen, Group C [28]. 
Mercury has no known essential functions, though it was at one time used to treat syphilis, with some success. Mercury probably affects the inherent protein structure, which may interfere with functions relating to protein production. Mercury has a strong affinity for sulfhydryl, amine phosphoryl, and carboxyl groups, and inactivates a wide range of enzyme systems, as well as causing injury to cell membranes. However, none of mercury's specific body interactions are clearly defined, though the main problems seem to result from its attack on the nervous system. Mercury may also interfere with some functions of selenium, and can be an immunosuppressant [29, 30]. The majority of the studies associated with mercury until now have been designed from a toxicological approach, including the measurement of the concentrations of mercury in various tissues and organs. Obtaining an increased knowledge of biological indicators of mercury exposure would prove to be the key to understanding and determining the toxic mechanisms of this metal at the cellular level. Hence, this research was therefore designed to assess the cellular and molecular responses of human liver carcinoma cells following exposure to mercury.

\section{Materials and Methods}

\section{Chemical and Growth Medium}

Reference solution of mercury $\left(10,000 \mu \mathrm{g} / \mathrm{mL}\right.$ in $\left.10 \% \mathrm{HNO}_{3}\right)$ CAS No. 7439-97-6, Lot No. B0095024 was purchased from EM Science, (Gibbstown, New Jersey). Dulbecco's Modified Eagle's Minimal Essential Medium was purchased from Life Technologies (Grand Island, New York). Penicillin-Streptomycin, Lot No. 1085899 and fetal bovine serum (FBS) were purchased from Gibco BRL Life Technologies (Grand Island, New York).

\section{Cell Culture}

$\mathrm{HepG}_{2}$ cells, a transformed human hepatoma cell line and recombinant $\mathrm{HepG}_{2}$ cell lines were obtained from Xenometrix, Inc. (Boulder, Colorado). In the laboratory, cells were stored in liquid nitrogen until use. They were next thawed by gentle agitation of their containers (vials) for 2 minutes in a water bath at $37^{\circ} \mathrm{C}$. After thawing, the content of each vial was transferred to a $75 \mathrm{~cm}^{2}$ tissue culture flask, diluted with DMEM supplemented with 10\% fetal bovine serum (FBS) and 1\% streptomycin and penicillin, and incubated for 24 hours at $37^{\circ}$ in a $5 \% \mathrm{CO}_{2}$ incubator to allow the cells to grow, and form a monolayer in the flask. Cells grown to $80-95 \%$ confluence were washed with phosphate buffer saline (PBS), trypsinized with $10 \mathrm{~mL}$ of $0.25 \%(\mathrm{w} / \mathrm{v})$ trypsin, $0.03 \%(\mathrm{w} / \mathrm{v})$ EDTA, diluted, counted, and seeded $\left(5 \times 10^{5}\right.$ cells/well) in two sets of 96 well microtiter tissue culture plates.

\section{Gene Profile and Cytotoxicity Assays}

The mammalian gene profile assay (CAT-Tox) was performed for measuring differential gene expression in immortalized human liver cells. The parental cell line $\left(\mathrm{HepG}_{2}\right)$, and thirteen different 
recombinant constructs generated by creating stable transfectants of different mammalian promoter chloramphenicol acetyltransferase (CAT) were obtained from Xenometric Inc. (Boulder, CO). Each construct contained a unique stress gene promoter or response element fused to the CAT reporter gene. Table 1 presents the promoter/response element-fusion constructs and their respective biological functions [31].

Seeded plates were incubated for 24 hours at $37^{\circ} \mathrm{C}$ in a $5 \% \mathrm{CO}_{2}$ incubator, followed by a replacement of the old medium by a fresh one containing the appropriate amount of each of the test chemical $(0,0.625,1.25,2.5,5$, and $10 \mu \mathrm{g} / \mathrm{mL}$ mercury) using deionized water as the solvent. For quality assurance/quality control purposes, positive control plates were also made using known inducers including 3-methyl cholanthrene (3-MC-10 $\mu \mathrm{M})$ for CYP 1A1, CRE, GADD45, p53RE, and XRE; methyl methane sulphonate (MMS-100 $\mu \mathrm{g} / \mathrm{mL}$ ) for GSTYa, HMTIIA, FOS, HSP70, NFkBRE, GADD153, and GRP78; and all trans retinoic acid (RA-10 $\mu \mathrm{M})$ for RARE. All chemical exposures involved the use of polypropylene 96-well microtiter plates for the purpose of chemical dilutions. A specific, constant volume $(20 \mu \mathrm{L})$ was transferred from each well of the chemical dilution plate to the plate containing the cells to give each cell line five chemical doses and a zero control dose, each in triplicates.

Table 1. Promoter/Response Element Fusions Constructs and Biological Functions

\begin{tabular}{|c|c|c|}
\hline Promoter & Name/Gene Product & Biological Function \\
\hline CYP1A1 & Cytochrome P450 1A1 & Phase I biotransformation enzyme \\
\hline GSTYa & Glutathione-S-Transferase & Phase II biotransformation enzyme \\
\hline HMTIIA & Metallothionein & Sequestration of heavy metals \\
\hline FOS & c-fos & Member of AP-1 transcription factor complex \\
\hline HSP70 & $70-\mathrm{kDa}$ heat shock protein & Protein chaperone/refold damaged protein \\
\hline GADD153 & $\begin{array}{l}\text { 153-kDa growth arrest/DNA } \\
\text { damage }\end{array}$ & Cell cycle regulation/response to genotoxic agents \\
\hline GADD45 & $\begin{array}{l}\text { 45-kDa growth arrest/ DNA } \\
\text { damage }\end{array}$ & Cell cycle regulation/response to genotoxic agents. \\
\hline GRP78 & $\begin{array}{l}78-\mathrm{kDa} \text { glucose related } \\
\text { protein }\end{array}$ & Endoplasmic reticulum protein chaperone \\
\hline XRE & $\begin{array}{l}\text { Xenobiotic Response } \\
\text { Element }\end{array}$ & $\begin{array}{l}\text { Binding site for Ah-receptor hydrocarbon } \\
\text { complexes }\end{array}$ \\
\hline NFkBRE & $\begin{array}{l}\text { Nuclear factor Kappa (B } \\
\text { Site) Element }\end{array}$ & Binding site for NFkB transcription factor \\
\hline CRE & cAMP response element & Binding site for CREB protein \\
\hline P53RE & $\begin{array}{l}53-\mathrm{kDa} \text { protein tumor } \\
\text { suppressor }\end{array}$ & $\begin{array}{l}\text { Binding site for } \mathrm{p} 53 \text { transcription factor/DNA } \\
\text { damage }\end{array}$ \\
\hline RARE & $\begin{array}{l}\text { Retinoic acid response } \\
\text { element }\end{array}$ & Binding site for retinoic acid receptor complex \\
\hline
\end{tabular}


Following chemical exposure, the cells were re-incubated for 48 hours at $37^{\circ} \mathrm{C}$ in $5 \% \mathrm{CO}_{2}$. After the incubation period, the total protein was measured by the Bradford method, at $600 \mathrm{~nm}$ using a microtiter plate reader (Bio-Tek Instruments Inc.) A standard sandwich ELISA was performed and in the final step, horse- radish peroxidase catalyzed a color change reaction that was measured at $405 \mathrm{~nm}$ $[32,33]$.

The parental $\mathrm{HepG}_{2}$ cell line was dosed in the same manner as the recombinant cell lines, and was used to perform the MTT [3-(4,5-dimethylthiazol-2yl)-2,5-diphenyltetrazolium bromide] - based cell viability assay using a microtiter plate reader (Bio-Tek Instruments, Inc.) with the wavelength set at $550 \mathrm{~nm}[34]$.

\section{Statistical Analysis}

The transcriptional fold inductions for each recombinant cell line at each mercury concentration were calculated using the CAT-Tox computer software based on the optical density readings at $600 \mathrm{~nm}$ and $405 \mathrm{~nm}$. The software also converted the $550 \mathrm{~nm}$ readings to cell viability percentages. Standard deviations were determined, and the Student's t-test values were computed to determine if there were significant differences in cell viability and gene induction in treated cells compared to the control cells. Graphs were made to illustrate the dose response relationship with respect to cytotoxicity and gene expression.

\section{Results}

Cytotoxicity Assay

The effects of mercury on the viability of the parental $\mathrm{HepG}_{2}$ cells are shown on Figure 1. Data presented in this figure indicate a strong dose-response relationship with respect to the cytotoxicity of mercury. Upon 48 hours of exposure, the average percentages of cell viability were $100 \pm 0 \%, 83.3 \pm$ $12.0 \%, 79.3 \pm 16.1 \%, 63.0 \pm 11.9 \%, 9.3 \pm 12.9$, and $2.5 \pm 1.1$ in $0,0.625,1.25,2.5,5$, and $10 \mu \mathrm{g} / \mathrm{mL}$ mercury, respectively (Figure 1). The $\mathrm{LD}_{50}$ value for mercury was computed to be $3.5 \pm 0.6 \mu \mathrm{g} / \mathrm{mL}$ upon 48 hours of exposure, indicating that mercury is highly toxic to the cells.

\section{Gene Profile Assay}

Data generated from the gene profile assay indicate that nine out of the thirteen recombinant cell lines tested showed inductions to statistically significantly levels $(\mathrm{p}<0.05)$ (Figures $2-10)$. Figure 2 shows a biphasic response with respect to mercury induction of the glutathione-S-transferase promoter with an increase in fold inductions up to $2.5 \mu \mathrm{g} / \mathrm{mL}$ and a decrease at higher concentrations of mercury. The fold inductions of this construct were $1.0 \pm 0.0,2.0 \pm 1.73,5.0 \pm 4.51,5.32 \pm 0.90,1.0 \pm$ 0.0 , and $1.0 \pm 0.0$ in $0,0.625,1.25,2.5,5$, and $10 \mu \mathrm{g} / \mathrm{mL}$ mercury, respectively, showing a strong dose response from 0 to $2.5 \mu \mathrm{g} / \mathrm{mL}$. 


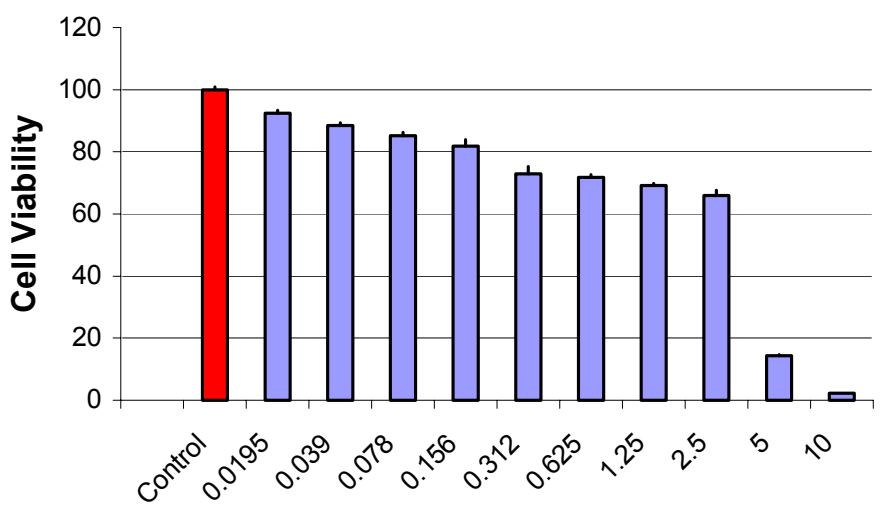

$\mathrm{Hg}(\mathrm{ug} / \mathrm{ml})$

Figure 1. Cytotoxicity of $\mathrm{HepG}_{2}$ cells to mercury at 48 hours of exposure. Data represent means \pm SDs, $\mathrm{n}=3$.



Figure 2. Fold induction of GSTYa in $\mathrm{HepG}_{2}$ cells exposed to mercury for 48 hours. Data represent means $\pm \mathrm{SDs}, \mathrm{n}=3$.

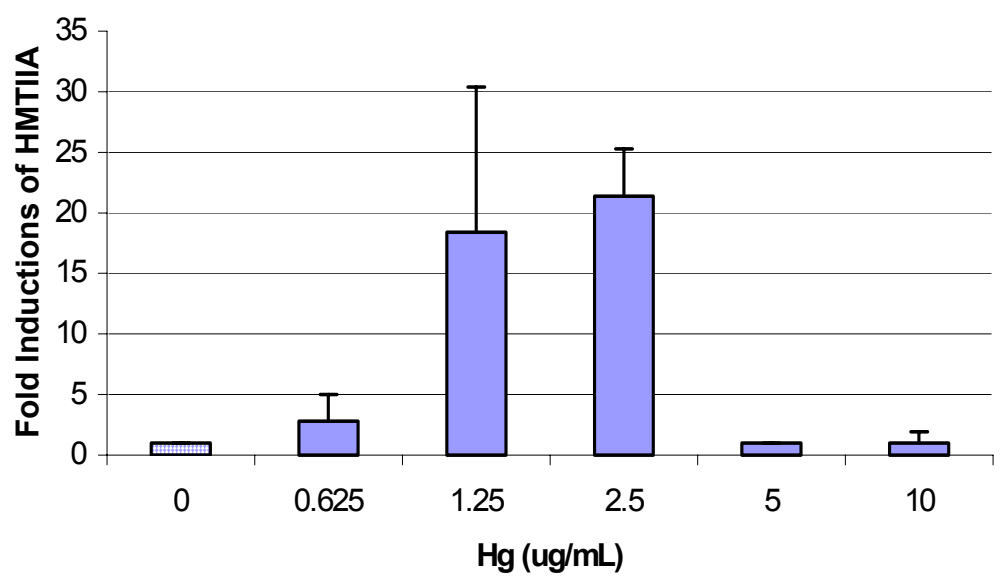

Figure 3. Fold induction of HMTIIA in $\mathrm{HepG}_{2}$ cells exposed to mercury for 48 hours. Data represent means \pm SDs, $n=3$. 


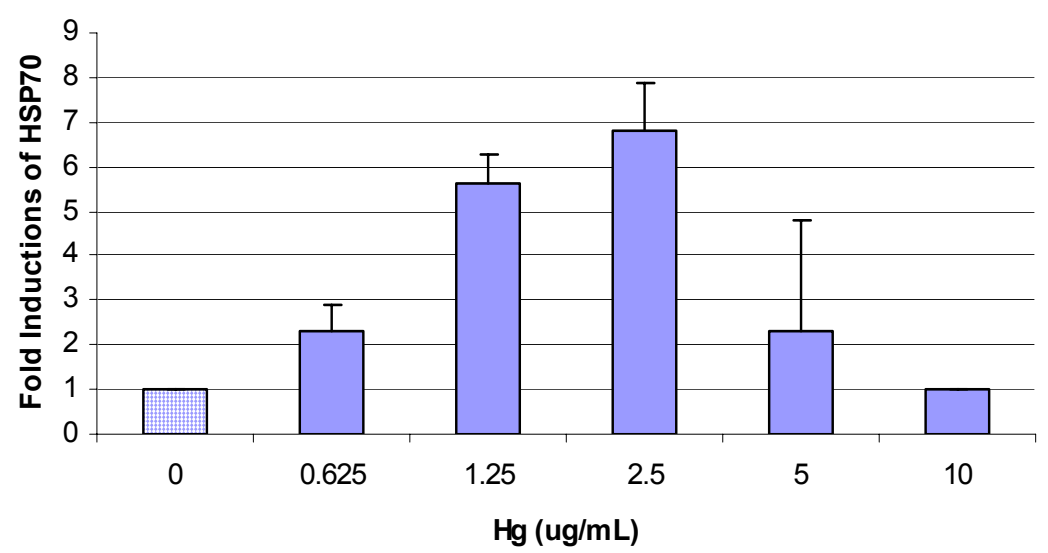

Figure 4. Fold induction of $\mathrm{HSP} 70$ in $\mathrm{HepG}_{2}$ cells exposed to mercury for 48 hours. Data represent means \pm SDs, $\mathrm{n}=3$.

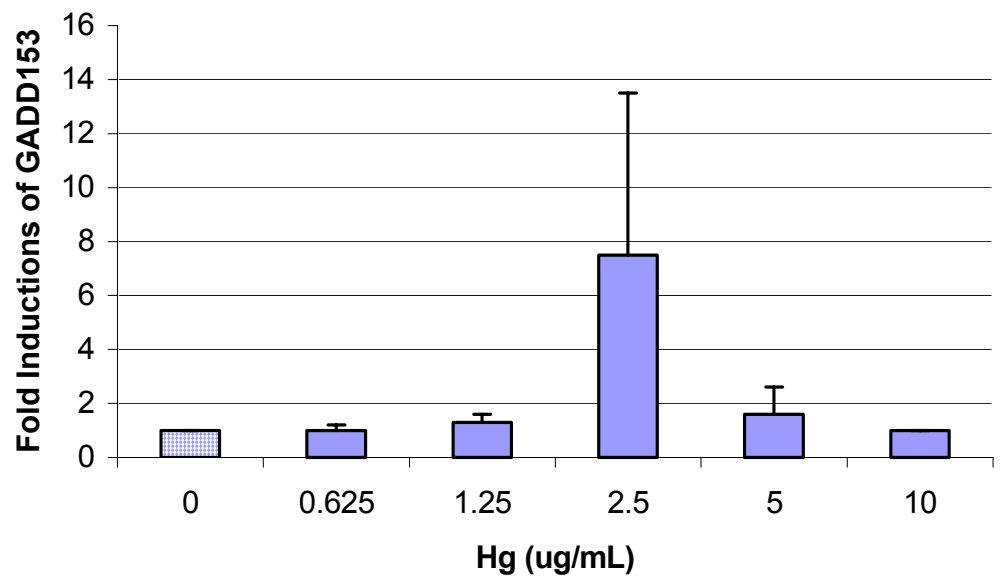

Figure 5. Fold induction of GADD153 in $\mathrm{HepG}_{2}$ cells exposed to mercury for 48 hours. Data represent means \pm SDs, $n=3$.

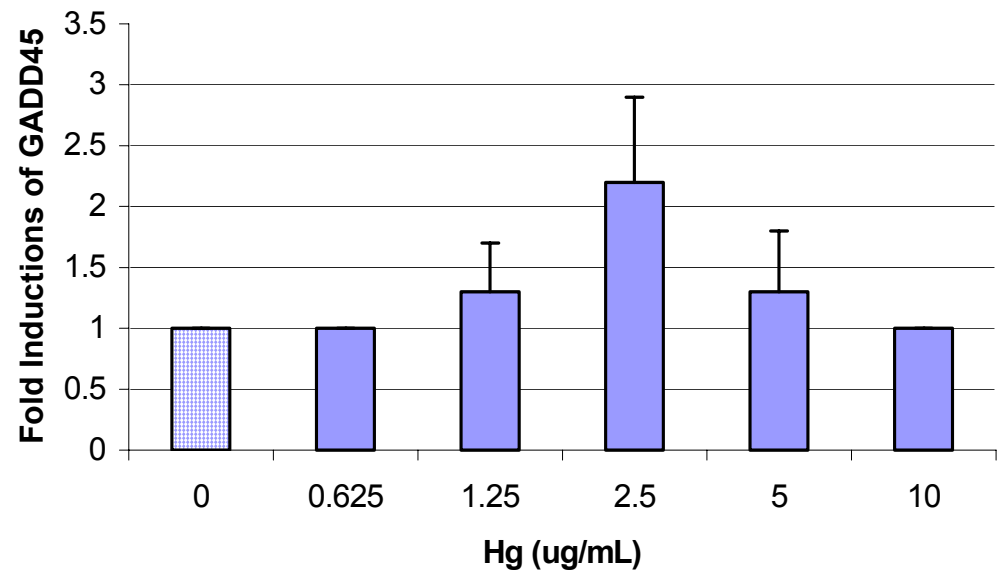

Figure 6. Fold induction of GADD45 in $\mathrm{HepG}_{2}$ cells exposed to mercury for 48 hours. Data represent means \pm SDs, $n=3$. 


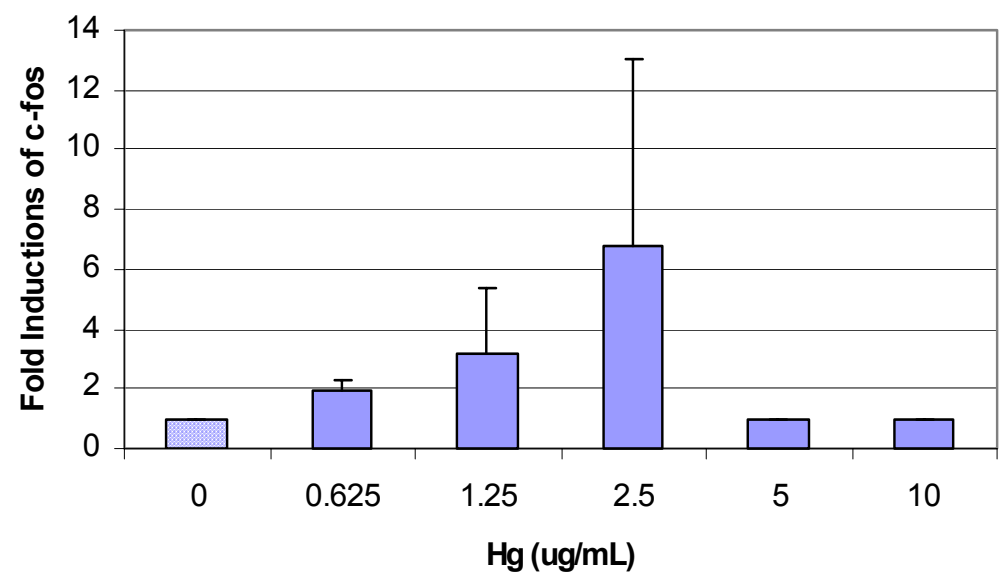

Figure 7. Fold induction of $c-f o s$ in $\mathrm{HepG}_{2}$ cells exposed to mercury for 48 hours. Data represent means \pm SDs, $n=3$.



Figure 8. Fold induction of p53RE in $\mathrm{HepG}_{2}$ cells exposed to mercury for 48 hours. Data represent means \pm SDs, $n=3$.

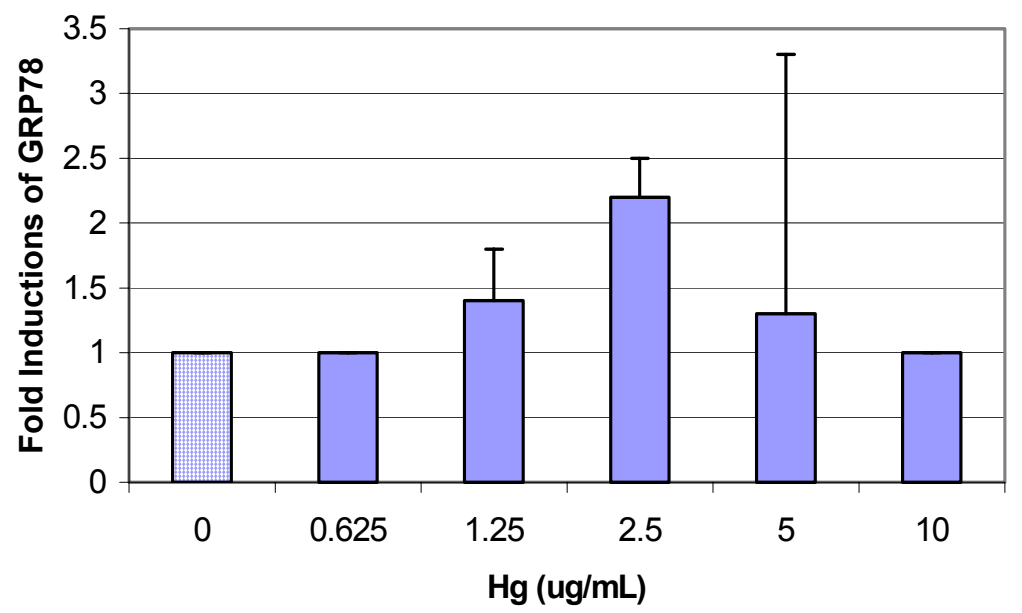

Figure 9. Fold induction of GRP78 in $\mathrm{HepG}_{2}$ cells exposed to mercury for 48 hours. Data represent means \pm SDs, $n=3$. 


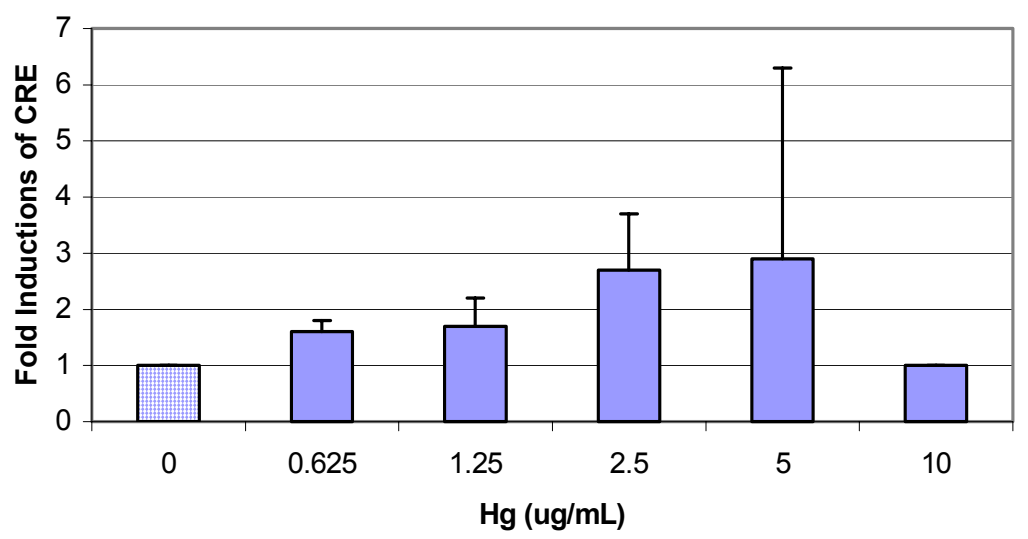

Figure 10. Fold induction of CRE in HepG2 cells exposed to mercury for 48 hours. Data represent means \pm SDs, $n=3$.

The induction levels of HMTIIA in human liver carcinoma cells exposed to mercury are shown in Figure 3. A biphasic response was obtained with respect to mercury induction of the metallothionein gene; with a gradual increase in fold inductions up to $2.5 \mu \mathrm{g} / \mathrm{ml}$, and a decrease at higher concentrations. The fold inductions of this construct were $1.0 \pm 0.0,2.80 \pm 2.17,18.39 \pm 12.0,21.41 \pm$ $3.94,1.52 \pm 0.90$, and $1.0 \pm 0.0$ in $0,0.625,1.52 .5,5$, and $10 \mu \mathrm{g} / \mathrm{mL}$ mercury respectively.

Figure 4 shows the induction levels of the HSP70 gene promoter in human liver carcinoma cells exposed to mercury. This figure also shows a biphasic response with respect to mercury inductions of HSP70. The fold inductions of this construct were $1.0 \pm 0.0,2.27 \pm 0.56,5.61 \pm 0.68,6.79 \pm 1.08$, $2.30 \pm 2.46$, and $1.0 \pm 0.0$ in $0,0.625,1.25,2.5,5$, and $10 \mu \mathrm{g} / \mathrm{mL}$ mercury respectively, indicating a strong dose response relationship between 0 and $2.5 \mu \mathrm{g} / \mathrm{mL}$.

Figure 5 shows the induction levels of the GADD153 gene promoter in human liver carcinoma cells exposed to mercury. The data shows a weak biphasic response with a moderate increase in fold inductions between 0 and $2.5 \mu \mathrm{g} / \mathrm{mL}$, and a moderate decrease at higher concentrations. The activity fold inductions of this construct were $1.0 \pm 0.0,1.01 \pm 0.23,1.32 \pm 0.31,7.53 \pm 6.0,1.57 \pm 0.99$, and $1.0 \pm 0.0$ in $0,0.625,1.25,2.5,5$, and $10 \mu \mathrm{g} / \mathrm{mL}$ of mercury, respectively.

Figure 6 shows the level of induction of the GADD45 promoter in human liver carcinoma cells. This data also shows a biphasic response with an increase in fold inductions from 0 to $2.5 \mu \mathrm{g} / \mathrm{mL}$, and a decrease at higher concentrations. The fold inductions of this construct were $1.0 \pm 0.0,1.0 \pm 0.17$, $1.25 \pm 0.35,2.16 \pm 0.68,1.29 \pm 0.50$, and $1.0 \pm 0.0$ in $0,0.625,1.25,2.5,5$, and $10 \mu \mathrm{g} / \mathrm{mL}$ of mercury, respectively.

Figure 7 shows the level of induction of the $c$-fos promoter in human liver carcinoma cells exposed to mercury. This data shows a biphasic response with respect to mercury induction of $c$-fos. There is a gradual increase in fold inductions within the concentration range of $0-2.5 \mu \mathrm{g} / \mathrm{mL}$ with a peak induction at $2.5 \mu \mathrm{g} / \mathrm{mL}$, followed by a sharp decrease at 5 and $10 \mu \mathrm{g} / \mathrm{mL}$. The fold inductions of this 
construct were $1.0 \pm 0.0,1.85 \pm 0.36,3.21 \pm 2.24,6.78 \pm 6.22,1.0 \pm 0.0$, and $1.0 \pm 0.0$ in $0,0.625$, $1.25,2.5,5$, and $10 \mu \mathrm{g} / \mathrm{mL}$ of mercury, respectively.

Figure 8, 9, and 10 show the inductions levels of p53RE, GRP78, and CRE in human liver carcinoma cells, respectively. The p53 construct shows a weak biphasic response with no increase in fold inductions until the 2.5 to $5 \mu \mathrm{g} / \mathrm{mL}$ concentrations and a sharp decrease at $10 \mu \mathrm{g} / \mathrm{mL}$. The activity fold inductions of this construct were $1.0 \pm 0.0,1.0 \pm 0.0,1.0 \pm 0.0,4.48 \pm 2.01,4.68 \pm 4,27$, and $1.0 \pm$ 0.0 in $0,0.625,1.25,2.5,5$, and $10 \mu \mathrm{g} / \mathrm{mL}$ mercury, respectively. The fold inductions of GRP78 were $1.0 \pm 0.0,1.0 \pm 0.0,1.35 \pm 0.40,2.44 \pm 0.31,2.13 \pm 1.96$, and $1.0 \pm 0.0$ in $0,0.625,1.25,2.5,5$, and 10 $\mu \mathrm{g} / \mathrm{mL}$ of mercury, respectively (Figure 9). Those of the CRE were $1.0 \pm 0.0,1.58 \pm 0.21,1.67 \pm 0.49$, $2.70 \pm 1.04,2.93 \pm 3.35$, and $1.0 \pm 0.0$ in $0,0.625,1.25,2.5,5$, and $10 \mu \mathrm{g} / \mathrm{mL}$ of mercury, respectively (Figure 10).

\section{Discussion}

\section{Cytotoxicity Assay}

This study demonstrated that mercury was highly toxic to transformed human hepatocytes. Upon 48 hours of exposure, the concentration required to reduce cell viability by $50 \%\left(\mathrm{LC}_{50}\right)$ was computed to be $3.5 \pm 0.6 \mu \mathrm{g} / \mathrm{mL}$. This result is in agreement with those of previous studies indicating the high degree of mercury toxicity to human liver carcinoma cells [35, 36]. A recent study by Tchounwou et al. [35] reported that mercury appears to be more toxic than cadmium to $\mathrm{HepG}_{2}$ cells. Using $\mathrm{HepG}_{2}$ cells at a test system, Tully et al. [37] conducted cytotoxicity experiments with various metal compounds including cadmium acetate, chromium (III) acetate, ammonium arsenate and lead nitrate dissolved in $1 \mathrm{mM}$ humic acid. For ammonium arsenate with a concentration range of $0-250 \mu \mathrm{M}$ the $\mathrm{HepG}_{2}$ cells showed a nearly linear decrease in cell viability over the range of tested concentrations with viability decreasing from $100 \%$ in the control to $69 \%$ at the highest tested concentration $(250$ $\mu \mathrm{M})$. Lead nitrate within a concentration range of $0-100 \mu \mathrm{M}$ had only a moderate effect on cell viability; decreasing cell viability to $84 \%$ at the highest tested concentration $(100 \mu \mathrm{M})$. Cadmium acetate within a concentration range of $0-15 \mu \mathrm{M}$ produced a nearly linear decrease in cell viability down to $62 \%$ at the highest tested concentration $(15 \mu \mathrm{M})$. Chromium (III) acetate within a concentration range of $0-750 \mu \mathrm{M}$ also produced a linear decrease in cell viability down to $62 \%$ at the highest tested concentration $(750 \mu \mathrm{M})$. Potassium dichromate within a concentration range of $0-10$ $\mu \mathrm{M}$, at doses nearly two orders of magnitude higher than those used for Chromium (III), the hexavalent chromium, caused a very sharp decrease in cell viability; down to $56 \%$ at the highest tested concentration $(10 \mu \mathrm{M})$.

Olivieri et al. [38] found that mercury induced cytotoxicity in a concentration dependent manner from as little as $10 \mu \mathrm{g} / \mathrm{L}$ to as much as $5000 \mu \mathrm{g} / \mathrm{L}$ (the maximum concentration tested over a 24 hour period) in SHSY5Y neuroblastoma cells exposed to mercuric chloride. Shenker et al. [39] treated human lymphoid cells with methyl mercuric chloride and mercuric chloride, and found that both 
mercury species affected the mitochondrial activity by inducing the development of a membrane permeability transition. They also found that both species of mercury were capable of activating the caspase cascade in the apoptotic process. Tchounwou et al. [40] conducted cytotoxicity experiments with $\mathrm{HepG}_{2}$ cells exposed to arsenic trioxide and found an $\mathrm{LC}_{50}$ of $11.95 \pm 2.61 \mu \mathrm{g} / \mathrm{mL}$; indicating that mercury is much more toxic to $\mathrm{HepG}_{2}$ cells than arsenic.

These studies clearly provides evidence that mercury is cytotoxic in a dose dependent manner, and that transformed human hepatocytes $\left(\mathrm{HepG}_{2}\right.$ cells) are viable candidates for the testing of heavy metal cytotoxicity, cell viability, and stress gene induction. Responses in cytotoxicity were clearly dose dependent.

The toxicity of mercury is primarily associated with the cationic state $\left(\mathrm{Hg}^{2+}\right)$, however absorption, tissue distribution, and biotransformations are all influenced by the valence state of the metal [41]. Mercury salts pose a greater health hazard to humans via ingestion, than metallic mercury. Typically, fatalities range from ingestion of 1 to 4 grams of mercuric chloride, although some have occurred with as little as 0.5 gram [42]. Symptoms of acute intoxication occur in two phases. Phase I is characterized by burning pain in the chest, discoloration of the oral mucous membrane, severe gastrointestinal pain, vomiting, bloody diarrhea, metallic taste, salivation, tachycardia, weak pulse, tachypnea, pallor, prostration, possible shock, circulatory collapse and death. If the patient survives to the third day, Phase II signs including mercurial stomatitis - characterized by glossitis and ulcerative gingivitis, loosening of the teeth, jaw necrosis, proximal tubular necrosis, resulting in transient polyuria, hematuria, anuria, and renal acidosis will appear. Other effects may include dysentry, tenesmus, colonic ulceration, capillary damage, liver necrosis, occasional tremors, peripheral neuropathies or other neurological effects. Death may occur from minutes to weeks after exposure $[43,44]$.

\section{Gene Profile Assay}

The induction levels of glutathione S-transferase in human liver carcinoma cells exposed to mercury are presented in Figure 2. Data pictured in this figure shows a strong dose response relationship regarding GSTYa induction within the concentration range of $0-2.5 \mu \mathrm{g} / \mathrm{mL}$. Inorganic mercury compounds have been found to cause the depletion of glutathione in cultured mammalian cells. Exposure to inorganic mercury compounds have also resulted in a two to three fold up regulation of mRNA encoding for g-glutamylcysteine synthetase, which is the rate limiting enzyme in glutathione synthesis $[45,46]$. Mercury has a high affinity for glutathione because it is cysteine rich and contains sulfhydryl groups. A single atom of mercury can bind to and cause the irreversible excretion of up to two glutathione tripeptides. Therefore, it has been demonstrated that mercury not only directly removes glutathione from the cell, but inhibits the activities of two key enzymes involved in glutathione metabolism; glutathione synthetase and glutathione reductase [47]. 
Figure 3 shows the induction levels of metallothionein in human liver carcinoma cells exposed to mercury. The data shows a strong dose response regarding metallothionein induction within the concentration range of $0-2.5 \mu \mathrm{g} / \mathrm{mL}$. This is expected, as it is an adaptive response to toxic metal exposure. Metallothioneins are a fascinating group of low molecular weight intracellular proteins that serve as a storage depot for copper, zinc, and "scavenge" sulfhydryl reactive metals (mercury) that enter cells. They are cysteine rich (approximately 30\%) and have a higher affinity for mercury than zinc [48]. Therefore, as mercury binds to metallothioneins and is restricted from entering the mitochondria, zinc is released. The importance of metallothioneins in the protection of the cell is evident because they provide an increased binding capacity for both toxic metals such as mercury (protective), and essential metals such as zinc (functional). Also, it has been shown that mammalian cell lines with the highest level of metallothioneins survived exposure to toxic metals such as cadmium $[49,50]$.

The induction levels of the $70-\mathrm{kDa}$ heat shock protein (HSP70) in human liver carcinoma cells exposed to mercury are shown in Figure 4. This data also shows a strong dose response regarding HSP70 induction within the concentration range of $0-2.5 \mu \mathrm{g} / \mathrm{mL}$. Heat shock proteins are expressed in response to conditions of environmental stress that include tissue damage, inflammation, oxidative stress, and mutated proteins associated with genetic abnormalities [51,52]. These proteins act as molecular chaperones, playing essential roles in mediating protein folding, assembly, transport, and degradation $[53,54]$. In cells exposed to hyperthermia, the induced synthesis of these proteins helps to prevent protein denaturation and aggregation, and to assist in the refolding and removal of damaged proteins. The induction of HSP70 indicates problems in protein synthesis, malfolding, and protein damage through mutations, all of which have been documented in the literature as mechanisms of inorganic mercury toxicity in mammalian cells [55]. The glucose-regulated protein (GRP78) is also activated by DNA damaging agents that cause mutations, and is clearly associated with genetic damage [56]. The induction levels of GRP78 in human liver carcinoma cells exposed to mercury are shown in Figure 9. This data indicates a biphasic response with regards to GRP78 induction, and a strong dose response within the concentration range of $0-2.5 \mu \mathrm{g} / \mathrm{mL}$.

The induction levels of $c$-fos in human liver carcinoma cells exposed to mercury are shown in Figure 7. This data also indicates a strong dose response regarding c-fos induction within the concentration range of $0-2.5 \mu \mathrm{g} / \mathrm{mL}$. This prototypical immediate early response gene is activated by a variety of stimuli, including activators of protein kinase-c [57,58], agents that increase intracellular cyclic AMP $[59,60]$, membrane depolarization or excitatory neurotransmitters such as glutamate that triggers an increase in the intracellular levels of $\mathrm{Ca}^{+2}$ [61], and peptide growth factors such as nerve growth factors (NGFs) that activate receptor tyrosine kinases [62, 63]. The induction of $c$-fos also indicates that mercury has the potential to induce cell proliferation [64]. The induction levels of the cAMP response element CRE in human liver carcinoma cells exposed to mercury are shown in Figure 10. This promoter responds specifically to increased intracellular levels of cAMP [65]. The data 
shows a strong dose response within the concentration range of $0-5 \mu \mathrm{g} / \mathrm{mL}$, and a sharp drop at the $10 \mu \mathrm{g} / \mathrm{mL}$ concentration.

Figures 5, 6, and 8 represent the induction levels of GADD153, GADD45, and p53RE in human liver carcinoma cells exposed to mercury. The 153-kDa growth arrest and DNA damage (GADD153) promoter responds to UV irradiation, X-rays, methyl methane sulfonate (MMS), n-methyl-nnitrosoguanidine (MNG) as well as calcium ionophores and other DNA-damaging agents [66, 67]. The 45-kDa growth arrest and DNA damage (GADD45) promoter responds to methyl methane sulfonate (MMS), methyl-n-nitrosoguanidine (MNG), and calcium ionophores also [68]. The p53 response element also responds to DNA damaging agents [69, 70, 71]. The fold induction levels of p53RE in human liver carcinoma cells are shown in Figure 8. This data also shows that while p53RE is significantly induced, it also does not follow the pattern of a strong dose response regarding inductions or a biphasic response. No significant inductions were observed for CYP1A1, XRE, NFkBRE, and RARE.

\section{Conclusions}

Findings from this study indicate that (a): acute exposure to inorganic mercury significantly $(\mathrm{p}<$ $0.05)$ reduces the viability of human liver carcinoma $\left(\mathrm{HepG}_{2}\right)$ cells; and $(\mathrm{b})$ : subacute exposure to inorganic mercury transcriptionally activates nine (GSTYa, HMTIIA, c-fos, HSP70, CRE, p53RE, GADD153, GADD45, and GRP78) of the thirteen gene promoters evaluated in the gene profile assay. These results indicate the potential of mercury to undergo Phase II biotransformation in the liver (GSTYa), to cause protein damage (HMTIIA, HSP70, and GRP78), cell proliferation (c-fos), metabolic perturbations (CRE), growth arrest and DNA damage (GADD45, GADD153), and apoptosis (p53RE). On the basis of these findings, it can also be concluded that metallothioneins and heat shock proteins, appear to be excellent candidates for detecting mercury induced proteotoxic effects at the cellular level.

Acknowledgements. This research was financially supported in part by a grant from the National Institutes of Health (Grant No. 1G12RR13459), through the RCMI-Center for Environmental Health, and in part by a grant from the U.S. Department of Education (Grant No. PO31B990006), through the Title III Graduate Education Program.

\section{References}

1. ATSDR/EPA. Priority List for 1999; Top 20 Hazardous Substances, Agency For Toxic Substance and Disease Registry. U. S. Department of Health and Human Services. 1999, on line at: http://www.atsdr.cdc.gov/99/list.html.

2. NAS. An assessment of mercury in the environment. National Academy of Science Press, Washington, D.C., 1978. 
3. Nriagu, J.O. Production and uses of mercury. In the biogeochemistry of mercury in the environment. Elsevier, Amsterdam, pp. 23-40, 1979.

4. Goyer, R. A. "Toxic effects of metals" in: Caserett and Doull's Toxicology - The basic science of poisons. McGraw-Hill, Inc., N.Y., 1993.

5. WHO. Inorganic mercury, Environmental Health Criteria 118. World Health Organization. 1991.

6. U.S. EPA (1997a). Mercury study report to congress, volume III: Fate and transport of mercury in the environment. U.S. Environmental Protection Agency, Office of Air Quality Planning \& Standards and Office of Research and Development. EPA-452/R-97-005. NTIS number: PB98124753, 1997.

7. Glass, G.E.; Sorensen, J.A.; Schmidt, K.W.; Rapp, G. R. New source identification of mercury contamination in the Great Lakes. Environ. Sci. Technol.. 1990, 24:1059-1069.

8. IRIS. Methyl mercury. Integrated Risk Information Service, last revised on 07/27/2001. Washington, D.C.; U.S. Environmental Protection Agency (U.S. EPA), 2001.

9. Trakhtenberg, L.M. Chronic effects of mercury on organisms. U.S. Department of Health, Education, and Welfare Public Health Service National Institutes of Health DHEW Publication No. (NIH) 74-473, 1974.

10. Kozik, M.B.; Gramza, G. Histochemical changes in the neurosecretory hypothalic nuclei as a result of an intoxification with mercury compounds. Acta Histochem. Suppl. 1980, 22, 367-380.

11. Gonzalez-Ramirez, D. et al; Urinary mercury, porphyrins, and neurobehavioral changes of Dental workers in Monterrey, Mexico. J. Pharmocology and Experimental Therapeutics. 1995, 272(1), 264-274.

12. Olanow, C.W.; Arendash, G.W. Metals and free radicals in neurodegeneration. Curr. Opin. Neurol. 1994, 7(6), 548-558.

13. Johnson, S. The possible role of gradual accumulation of copper, cadmium, lead, and iron depletion of zinc, magnesium, selenium, vitamins B2, B6, D, and E and essential fatty acids in multiple sclerosis. Med Hypotheses. 2000, 55(3), 239-241.

14. Ladner, L.; Lindestron, L. Copper in society and the environment. Environmental Research Group (MFG), $2^{\text {nd }}$ revised edition, 1999.

15. Boot, J.H. Effects of SH-blocking compounds on the energy metabolism in isolated rat hepatocytes. Cell. Struct. Funct. 1995, 20(3), 233-238.

16. Matts, R.L.; Schatz, J.R.; Hurst, R.; Kagen, R. Toxic heavy metal ions inhibit reduction of disulfide bonds. J. Biol Chem. 1991, 266(19), 12695-12703.

17. Khera et al. Teratogenic and genetic effects of mercury toxicity. Teratology. 1990, 8, 293-304.

18. O’Halloran, T.V. Transition metals in control of gene expression. Science 1993, 261(5122), 715 725.

19. Goyer, R.A. Nutrition and metal toxicity. Am. J. Clin. Nutr. 1995, 61(suppl 3), 545S-650S.

20. Kubicka et al. Autoimmune disease induced by mercuric chloride. Int Arch Allergy Immunol. 1996, 109(1), 11-20. 
21. McFadden, S.A. Xenobiotic metabolism and adverse environmental response: sulfur dependent detoxification pathways. Toxicology. 1996, 111(1-3), 43-65.

22. Srikantarah, M.V.; Radjakushnan, A. N. Studies on the metabolism of vitamin B6 in the small intestine. Purification and properties of monkey intestinal pyridoxal kinases. Indian J. Biochem. 1970, 7(3), 151-156.

23. Veltman, J.C. Alterations of heme cytochrome P-450, and steroid metabolism by mercury in rat adrenal gland. Arch Biochem Biophys. 1986, 248(2), 467-478.

24. Danielson, B.R. Ferotoxicity of inorganic mercury: Distribution and effect of nutrient uptake by placenta and fetus. Neurotoxicol. Teratol. 1984, 18, 129-134.

25. Kubicka-Murranyi, M. "Systemic autoimmune disease induced by mercuric chloride. Int Arch Allergy Immunol. 1996, 109(1), 11-20.

26. U. S. EPA. Mercury study report to congress. Volume V: Health effects of mercury and mercury compounds. U. S. Environmental Protection Agency, Office of Air Quality Planning and Standards and Office of Research and Development. EPA-452/R-97-005. NTIS number: PB9812444753, 1997.

27. WHO. Inorganic mercury volume 118. Geneva, Switzerland: World Health Organization, 1991.

28. IRIS. Mercuric chloride. Integrated Risk Information Service, last revised on 4/01/97. Washington, D.C.; U.S. Environmental Protection Agency (U.S. EPA), 1997.

29. Kaik, P. Clinical and neurochemical aspects of inorganic mercury intoxification. In handbook of clinical neurology, Elsevier, Amsterdam , 36, 147-197, 1979.

30. Takizawa, Y. The epidemiology of mercury poisoning. In the biogeochemistry of mercury in the environment, Nriagu, J.O. eds Elsevier, Amsterdam pp. 325-366, 1979.

31. Todd, M.D.; Lee, M.J.; Williams, J.L.; Nalenzy, J.M.; Gee, P.; Benjamin, M.B.; Farr, S.B. The CAT-Tox (L) assay: A sensitive and specific measure of stress induced transcription in transformed liver cells. Fundam. Appl. Toxicol. 1995, 28, 118-128.

32. Tchounwou, P.B.; Wilson, B.A.; Schneider, J.; Ishaque, A. Cytogenic assessment of arsenic trioxide toxicity in the Mutatox, Ames II and CAT-Tox assays. Metal Ions Biol. Med. 2000, 6, 89-91.

33. Todd, M.D.; Lee, M.J.; Williams, J.L.; Nalenzy, J.M.; Gee, P.; Benjamin, M.B.; Farr, S.B. The CAT-Tox (L) assay: A sensitive and specific measure of stress induced transcription in transformed liver cells. Fundam. Appl. Toxicol. 1995, 28, 118-128.

34. Tchounwou, P.B. Health risk assessment and management of arsenic and other hazardous metals in drinking water. Metal Ions Biol. Med. 2000, 6, 21-23.

35. Tchounwou, P.B.; Ishaque, A.B.; Schneider, J. Cytotoxicity and transcriptional activation of stress genes in human liver carcinoma cells $\left(\mathrm{HepG}_{2}\right)$ exposed to cadmium chloride. Molecular and Cellular Biochemistry. 2001, 222, 21-28.

36. Tchounwou, P.B.; Ishaque, A.B.; Sutton, D.J.; Ninashvili, N.; Shen, E. Biomarkers of sensitivity and effect associated with cadmium and mercury toxicity in human liver carcinoma $\left(\mathrm{HepG}_{2}\right)$ cells. Metal Ions in Biology and Medicine. 2002, 7, 132-137. 
37. Tully, D.B.; Collins, B.J.; Overstreet, J.D.; Smith, C.S.; Dinse, G.E.; Mumtaz, M.M.; Chapin, R.E. Effects of arsenic, cadmium, chromium, and lead on gene expression regulated by a battery of 13 different promotes in recombinant $\mathrm{HepG}_{2}$ cells. Toxicology and Applied Pharmacology. 2000, 168, 79-90.

38. Olivieri, G.; Brack, C.; Muller-Spahn, F.; Stahelin, H.B.; Herrmann, M.; Renard, P.; Brockhaus, M.; Hock,C. Mercury induces cell cytotoxicity and oxidative stress and increases $\beta$-amyloid secretion and tau phosphorylation in SHSY5Y neuroblastoma cells. Journal of Neurochemistry. 2000, 74, 231-236.

39. Shenker, B.J.; Guo, T.L.; Shapiro, I.M. Mercury induced apoptosis in human Lymphoid cells: Evidence that the apoptotic pathway is mercurial species dependent. Environmental Research. 2000, 84, 89-99.

40. Tchounwou, P.B.; Wilson, B.A.; Ishaque, A.B. Embryotoxicity of arsenic trioxide and Atrazine to Japanese Medaka (Oryzias latipes), and cytotoxicity to human liver carcinoma cells $\left(\mathrm{HepG}_{2}\right)$. Env. Toxicol. Risk Assessment 2000, 10, 83 - 95.

41. Berlin, M. Mercury, In: Handbook on the toxicology of metals $2^{\text {nd }}$ edition, Frieberg, G.R.; Norber, V.B.; Vouk, B. ed. New York:Elsevier Press. 1980.

42. ATSDR. Toxicological Profile for Mercury: TP-93/10. Agency for Toxic Substance And Disease Registry. Centers for Disease Control. Atlanta, Georgia, 1994.

43. Gosselin, R.E.; Smith, R.P.;Hodge, H.C. Mercury In: clinical toxicology of commercial produces, $5^{\text {th }}$ edition, Baltimore, Maryland: Williams and Wilkins, pp. III262 - III275. 1984.

44. Troen, P.; Kaufman, S.; Katz, K.H. Mercuric bichloride poisoning. New England J. Med. 1951, 244, 459-463.

45. Rushmore, T.H.; Pickett, C.B. Glutathione S-transferases: structure, regulation, and therapeutic implications. J. Biol. Chem.. 1993, 268, 11475-11478.

46. Rushmore, T.H.; King, R.G.; Paulson, K.E.; Pickett, C.B. Regulation of glutathione S-transferase Ya subunit gene expression: Identification of a unique xenobiotic responsive element controlling inducible expression by planar aromatic compounds. Proc. Natl. Acad. Sci.. 1990, 87, 38263830 .

47. Zalups, R.K.; Lash, L.H. Interactions between glutathione and mercury in the kidney, liver and blood. In: Chang, L.W., ed. Toxicology of Metals. Boca Raton: CRC Press; 1996:145-163.

48. Hamer, D.H. Metallothionein. Ann. Rev. Biochem.. 1986, 55, 913-951.

49. Burman, D.M.; Palmiter, R.D. Analysis of detoxification of heavy metal ions by mouse metallothionein. EXS. 1987, 52, 457-463.

50. Klassen, C.D.; Liu, J. Induction of metallothionein as an adaptive mechanism affecting the magnitude and progression of toxicological injury. Environ. Health Perspect. 1998, 106, 297 300 .

51. Mosser, D.D.; Duchanie, J.; Massie, B. The DNA-binding activity of the human heat shock transcription factor is regulated in vivo by hsp70. Mol. Cell. Biol.. 1993, 13, 5427-5438. 
52. Mosser, D.D.; Theodorakis, N.G.; Morimoto, R.I. Coordinate changes in heat shock element binding activity and HSP70 gene transcription rates in human cells. Mol. Cell. Biol.. 1988, 8, 3733-3736.

53. Hartl, F.U.; Martin, J.; Neupert, W. protein folding in the cell: The role of molecular chaperones HSP70 and HSP60. Annu. Rev. Biophys. Biomol. Struct.. 1992, 21, 293-322.

54. Delmas, R.; Schaak, S.; Gaubin, Y.; Croute, F.; Arrabit, C.; Murat, J. C. HSP72 mRNA production in cultured human cells submitted to non-lethal aggression by heat, ethanol, or propanol. Application to the detection of low concentration of chromium (VI) (potassium dichromate). Cell. Biol. Toxicol.. 1998, 14, 39-46.

55. Brookes, N.; Kristt, D.A. Inhibition of amino acid transport and protein synthesis by $\mathrm{HgCl}_{2}$ and methyl mercury in astrocytes: selectivity and reversibility. Journal of Neurochemistry. 1989, 53(4), 1228-1237.

56. Wooden, S.K.; Li, L.J.; Navarro, D.; Qadri, I.; Pereira, L.; Lee, A.S. Transactivation of the grp78 promoter by malfolded proteins, glycosylation block, and calcium ionophore is mediated through a proximal region containing a CCAAT motif, which interacts with CTF/NF-1. Mol. Cell. Biol.. 1991, 11, 5612-5623.

57. Buscher, M.; Rahmsdorf, M; Litfin, M.; Herrlich, P. Activation of the c-fos gene by UV and phorbol ester: different signal pathways converge to the same enhancer element. Oncogene. 1988, 3, 301-311.

58. Gilman, M.Z. The c-fos serum response element responds to protein kinase c-dependent and independent signals but not to cyclic AMP. Genes Dev.. 1988, 2, 394-399.

59. Berkowitz, L.A.; Riabowal, K.T.; Gilman, M.Z. Multiple sequence elements of a single functional class are required for cyclic AMP responsiveness of the mouse c-fos promoter. Mol. Cell. Biol.. 1989, 9, 4722-4731.

60. Sassosne-Corsi, P; Visvander, J.; Ferland, L; Mellon, P.; Verma, L.N. Induction of protooncogene fos transcription through the adenylate cyclase pathway: characterization of cAMP response element. Genes Dev.. 1988, 2, 1529-1538.

61. Bading, H.; Ginty, D.D.; Greenbert, M.E. Regulation of gene expression in hippocampal neurons by distinct calcium signaling pathway. Science, 1993, 260, 181-186.

62. Ginty, D.D.; Bonni, A.; Greenberg, M.E. Nerve growth factor activates a Ras dependent protein kinase that stimulates c-fos transcription via phosphorylation of CREB. Cell. 1994, 77, 713-725.

63. Greenberg, M.E.; Ziff, E.B.; Green, L.A. Stimulation of neuronal acetylcholine receptors induce rapid gene transcription. Science. 1986, 234, 80-83.

64. Angel, P. Karin, M. The role of Jun, Fos and the AP-1 complex in cell proliferation and transformation. Biochem. Biophys. Acta. 1991, 1072, 129-157.

65. Borrelli, E.; Montmayeur, J.P.; Foulkes, N.S.; Sassone-Corsi, P. Signal transduction and gene control:The cAMP pathway. Crit. Rev. Oncog.. 1992, 3, 321-338.

66. Fornace, A.J. Jr.; Nerbert, D.W.; Hollander, M.C.; Leuthy, J.D.; Papthanasiou, M.; Fargnoli, J.; Holbrook, N.J. Mammalian genes coordinately regulated by growth arrest signals and DNAdamaging agents. Mol. Cell. Biol. 1989, 9, 4196-4203. 
67. Hollander, M.C.; Alamo, L.; Jackman, J.; Wang, M.G.; McBride, O.W., Fornace, A.J., Jr. Analysis of the mammalian gadd45 gene and its response to DNA damage. J. Biol. Chem.. 1993, 268, 24384-24393.

68. Bartlett, J.D.; Leuthy, J.D.; Carlson, S.G.; Sollott, S.J.; Holbrook, N.J. Calcium ionophore A23178 induces expression of the growth arrest and DNA damage inducible CCAAT/enhancerbinding protein (C/EBP)-related gene, gadd153. J. Biol. Chem.. 1992, 267, 20465-20470.

69. Kastan, M.B.; Onyekwere, O.; Sidransky, D.; Vogelstein, B.; Craig, R.W. Participation of p53 protein in the cellular response to DNA damage. Cancer Res.. 1991, 51, 6304-6311.

70. Vogelstein, B.; Kinzler, K.W. p53 function and dysfunction. Cell 1992, 70, 523-526.

71. Zhan, Q.; Carrier, F.; Fornace, A.J. Induction of cellular p53 activity by DNA-damaging agents and growth arrest. Mol. Cell. Biol.. 1993, 13, 4242-4250.

(C) 2002 by MDPI (http://www.mdpi.org). 